DOI: $10.5937 /$ kom $1803053 \mathrm{M}$

Original scientific paper

\title{
THE ETHICAL VIEWS OF ISLAM IN INTERNATIONAL RELATIONS
}

\author{
Seyed Mehdi Taheri
}

Al-Mustafa International University, Qom, Iran

\author{
Mohammad Reza Dodhiya \\ Al-Mustafa International University, Qom, Iran
}

Given the intrinsic orientation of humankind towards society, humans in their mutual life form communities at different levels, such as families, tribes, ethnic groups, nations, and the world. The primary goal in such a formation is self-interest. However, various conflicting interests inevitably lead to disputes and complications. Therefore, in order to avoid the harmful consequences of such situations and also to avail self-interest, humans are in need of some definite criteria. One of the most important levels of human interaction happens on the international level. This includes relations between governments, foreign groups, organizations and even individuals of different countries. These relationships remain immune to vulnerability as long as they are based on reasonable and intellectual standards.

Many schools and thoughts have been pursued in order to find the most productive one in various fields, including that of international relations. Among many religions, sects and schools, Islam, emphasizing the value of justice, provides a comprehensive set of criteria based upon ethics and sharia for the purpose of regulating human relations in the international arena. In light of the aforementioned view, the authors, by referring to various resources in library-oriented research, seek to utilize the data in a descriptive-analytical methodology, in trying to investigate the question of what the approach of Islam is with regard to ethics in international relations.

The authors firmly believe that Islam, in the ranks of the normative or value theories of international relations, deals with the dangers and failures

Corresponding author: seyedmehditaheri@gmail.com

Corresponding author: reza.dodhiya@gmail.com 
of international relations theories and describes and prescribes international relations as it ought to be, putting emphasis on the ethical approach.

Keywords: Ethics, international relations, Islam, Quran, religion

\section{Introduction}

One of the major issues in international relations is the role of ethics and its observance (or non-observance) on the global scale, as well as its role and success in leading and guiding governments. Various international relations theories have been constructed based on discussions of the role of ethics and human values in international politics. In general, three types of relations can be outlined:

Group 1: Negligence of ethical Values: This group includes pro-positivist theories which seek to explain the visible elements, their peculiar conditions and the relationship between them while objectively neglecting the ethical values behind them. Based upon the views of positivists, the academic theories in the field of international relations should lead to a theory similar to the theories of natural sciences, which are objectively free from any moral values and judgments.

Group 2: Describing moral values without any behavioral and practical implications: This group includes post-positivist theories according to which, and contrary to the claims of positivists, pure objective and empirical theorizing of ethics and moral values in international relations is not possible. At the same time, this group describes the personal and social ethical values as mere facts of international relations and does not go further into judging the truth or the wrongness of the values and ethics.

Group 3: The use of ethical values and morals constitute an important part of the theory: This group includes theories that consider values and ethics as central and as the main components of a theory. They address the do's and don'ts of international relations and proliferate the international relations as it ought to be. The theories in this group consider normative values in international relations, including the structuralism theory, according to which a system of beliefs, values and common norms, including ethical rules and norms, has structured characteristics which influence and affect the behavior of international actors (Dehghani Firoozabadi 2009).

In light of the aforementioned views, the authors of this article seek to examine the question of what approach Islam has in relation to the ethical principles in international relations. 
In response to this question, the authors believe that Islam, in the ranks of the normative or value theories of international relations, deals with the dangers and failures of international relations theories, and describes and prescribes international relations as they ought to be, putting emphasis on the ethical approach.

\section{Literature Overview}

With regard to the literature review on the present topic, it should be mentioned that scholarly works available can be categorized in the following areas:

Some scholars have studied ethics and political ethics in international relations in the theoretical field. This includes the collection of articles on ethics and international relations with the efforts of Mehdi Zakerian and the collection of articles on political ethics with the efforts of Nima Kiani.

In his book Ethics and International Relations, the author analyzes the relationship between ethics and politics and puts the two categories of theoretical and applied ethics into his agenda. He explains and criticizes the views of scholars and non-Iranian academics, in addition to providing the initial design of Islamic view in this regard (Zakerian 2011). In the 'collection of articles on political ethics', the author examines topics such as political morality from the perspective of Islam, political morality in contemporary theories, political and political ethics, political morality and progress, political morality and political thought, and political morality in world politics and international relations (Kiani 2009).

Other related works in this area are concerned with the do's and don'ts in Islam with regard to international relations. The most important work in this regard is the book International relations in Islam by Ayatollah Javadi Amoli. The author focuses on the theoretical aspects and foundations of social relations in the international arena from the Islamic perspective and lays emphasis on 'human nature' as the focal point of these relations. He also explains the causes and the flaws in the current laws of human relations in the world (Javadi Amoli 2009).

The next field of research studies includes the Shiite and Sunni jurisprudential principles of international relations, which have been studied by authors such as Seyyed Mahmoud Alavi and Khalil Arif Abu 'Id.

Alawi, in his book, refers to the jurisprudential rules that have a fundamental impact on international relations. He outlines the form, direction and objectives of foreign affairs in an Islamic Government (Alavi 2007). Abu 'id, in his work, uses first hand sources like the Book, narrations, and the actions of the caliphs in order to underline the principles of Islam and 
also to provide an Islamic framework in regulating international relations (Abu 'Id 2012).

Other relevant research literature is the one focusing on the discussion of political behavior and foreign relations of the Islamic state, as done by Abdul-Qayyum Sajjadi in his book Diplomacy and political behavior in Islam and Muhammed Hamidullah in his book International demeanor of the Islamic State.

In his book, Sajjadi seeks to explore political interactions from the position of Islam and highlights the relevant points in contemporary political morality and science. In doing so, he examines the principles of diplomatic behavior in international relations, its nature and principles, the characteristics of diplomacy in Islam, its objectives and tools, and finally, with the help of historical evidence, he explains the evolution of Islamic diplomacy from the era of the Prophet and the chosen (Rashidin) caliphs (Sajjadi 2004). Hamidullah, in his work, examines the subjects of peace and diplomacy while also analyzing the generalities of Islamic international law and, finally, he discusses hostile and impartial relations (Hamidullah 2001).

To add to the literature mentioned previously, research done in the fields of peaceful coexistence in Islam and international law, which examines the comparative study of Islamic principles and international law, is also worth mentioning.

In light of the scholarly literature available pertinent to the topic, the authors seek to study the ethical principles prescribed by Islam to govern international relations. In doing so, the academics seek to use the original sources of Islam such as the Holy Quran and the narrations, while also making use of the aforementioned scholarly literature.

It seems necessary to note that the theories of international relations, under the influence of the Western states, have set secular policies as a peaceful, stable and universal base for international relations. Similarly, the main goal of these theories has been to maintain the existing international status or to establish a desirable global order under the influence of the West. Although the norms of international relations have been under the influence of major powers, so far they have been unable to fully analyze the foreign policies of countries that have a different historic, cultural and value structure with that of the Western governments.

In this regard, our claim is that the idea prescribed by Islam about international relations includes theories which express a system of ideas or a set of related and consistent logical propositions that not only consider the interests of Islamic nations and governments but also goes beyond that. The system provides a framework for a just and fair international arrangement in which humans (in both personal and collective terms) reach 
perfection and prosperity. It seeks the interests of humanity, as a whole, throughout the world.

\section{Principles and Objectives of International Relations}

The religion of Islam seeks to design and establish a global moral community beyond the national government in order to realize human and moral values in the framework of a political community in a transnational justice-based system. In such a moral-political community, Islam strives to provide security and prosperity to all humankind. In this regard, God and justice are pivotal in the foundation of international Islamic relations.

God is the pivot and the core of thought in every Islamic system, in the domestic as well as in the international arena. Therefore, the main focus in all these areas ought to fall within the framework of divine laws and ordinances.

The second pivotal component of the Islamic system is Justice. None of the decisions should violate justice. The criteria of justice include the judgement which is in line with the command of God. Based on this value, the Islamic government strives to implement justice in the world. Therefore, it cannot be compassionate and lenient towards oppressive governments and it cannot disregard the oppressed. In this regard, Imam Khomeini states: "We must work with the people of the world, address their problems, address the affairs of Muslims around the world, support those who are fighting injustice, the hungry and the deprived with all our existence. This must be understood as the principles of our foreign policy" (Imam Khomeini 1990: XX/140).

With regard to the goals of international relations, it should be noted that, based on the dominant ideas in the contemporary world, power is the ultimate goal of politics (Duverger 1979: 3). Accordingly, the goal of governments in gaining power is to subjugate others in order to secure their own material interests. In Islam, power is regarded as a mere means to implement divine orders and to realize the ethical principles derived from it. Thus, the ultimate goal of gaining power in Islam is to achieve prosperity and human perfection.

Achieving this goal requires preliminaries such as the revelation of the book and the sending of prophets. In various Quranic verses and Prophetic narrations, this aim has been mentioned under different titles, some of which are:

- Establishing social justice: "Certainly we sent our apostles with manifest proofs, and we sent down with them the book and the balance, so that mankind may maintain justice" (Quran 57: 25). 
- Guidance and steering of human societies: "[This is] a book We have sent down to you that you may bring mankind out from darkness into light, by the command of their Lord" (Quran 14: 1).

- Completion of moral wisdom: "I have been chosen to complete the moral wisdom" (Tabataba'i 1994: XIX/377).

The totality of these goals is considered to be the basis for the ultimate goal of creation, i.e. prosperity and human perfection.

\section{Ethical Principles Based on Islamic International Relations}

Religion has been an influential element in the life of human beings throughout history. In recent years, it has gained special importance in international equations as well. In comparison with other religions, Islam is a comprehensive, all-encompassing, eternal religion that does not target a particular race or group, nor does it bound itself to a specific time or place. Rather, the message of Islam is universal, regardless of the person's race and nationality, language and culture, thoughts and beliefs. Islam follows the principles of ethics in the international arena, the international commandments of Islam are based upon ethical principles, the most important of which are referred to as follows:

\subsection{The Unity of Societies Based on the Pure, Inherent Human Nature}

Since human beings are dependent upon their society in order to attain peace and prosperity, they are in need of harmony and reconciliation with fellow humans. In spite of the difference between people in terms of race, language, religion, customs, traditions, etc., the fundamental axis of human unity and the unity of human societies lies in their monotheistic nature, which none of the contradictory elements affects it. If humans are to interact with one another on the basis of their pure inherit nature, they will have a peaceful life. Similarly, engagement with non-Muslims can also be realized under this shared human principle (Jawadi Amoli 2009: 140-143).

\subsection{The Principle of Equality of All Nations}

Islam tries to reject various divergent factors by building unity of thought among all human beings. It promotes a fundamental thought that all human beings are equal and no-one is superior to the others. Therefore, the most 
fundamental principle for equality and its accomplishment is to adhere to the principle of human dignity and to negate supremacy in the international arena. Islam condemns everything that rejects these two principles.

\subsubsection{Human Dignity}

Since all human beings are created in the image of God and are considered to be His servants, each person, regardless of their persona, has the right to be respected. This is known as 'the principle of human dignity'. In accordance to this principle, Non-Muslims, who do not share the same view like the Muslims, ought to be respected as they share the common values of humanity and human dignity with their fellow Muslims. As Allah Almighty has said in the Holy Quran: "That is why we decreed for the children of Israel that whoever kills a soul, without (its being guilty of) manslaughter or corruption on the earth, is as though he had killed all mankind, and whoever saves a life is as though he had saved all mankind" (Quran 5: 32).

\subsubsection{Rejection of Ethnicity and Racism}

One of the important areas which the Islamic thought in international relations firmly pursues is the liberation of nations regardless of their race. This liberation involves tackling injustices and inequalities within the framework of a ruling independent and self-determined international order. One of the instances of liberation that the Islamic theory of international relations seeks to objectify is a liberation from ethnic and racial discrimination. Though the issue of ethnic and racial discrimination has long been proposed by the Western countries and their organizations, in most cases it has largely been used as a catchphrase. This is why, in the context of the Islamic theory of international relations, it is firmly believed that the attribute of humanity (irrespective of a person's race and ethnicity) ought to be respected. This is the focal axis for the development of a moral world which would serve as a factor of unity and international affiliations. Accordingly, the Holy Quran condemns any racist thoughts and views all human beings as children of a parent without taking into consideration their ethnic, racial or religious superiority. "O Mankind! Indeed, we created you from a male and a female, and made you nations and tribes that you may identify with one another. Indeed, the noblest of you in the sight of Allah is the most Godwary among you. Indeed, Allah is all-knowing, allaware" (Quran 49: 13). 


\subsection{The Principle of Non-Violent Intervention \\ to Promote Belief (Freedom of Choice)}

According to Islamic teachings, Muslims should not resort to forceful practices in promoting their religious beliefs among other religions and nationalities. In the chapter of Baqarah, Allah Almighty has reminded the Muslims about this principle, 'There is no compulsion in religion' (Quran 2:256).

In another instance He addresses the Prophet saying, "And had your Lord wished, all those who are on earth would have believed. Would you then force people until they become faithful?" (Quran 10: 99)

Similarly, The Prophet was ordered to communicate the divine orders re-

gardless of whether the adversaries believed in them or not. "And say: [This is] the truth from your Lord; let anyone who wishes believe it. And let anyone who wishes disbelieve it" (Quran 18: 29).

In light of the aforementioned verses, it can be concluded that faith in God is never imposed. The important factor is that the divine truths and instructions should be expressed so that people become familiar with it, but as far as accepting and following them is concerned, it is to be done by the free will and authority of the people themselves and not through the use of force.

In the contemporary world where some religions in different parts of the world do not permit themselves to even question the bases of their beliefs, adhering to the principle of non-interventionist participation in promoting belief will drastically reduce the level of conflict in international relations.

\subsection{The Principle of Negation of Domination}

The Holy Quran refers to this principle by mentioning, 'God has not put a domination nor a way for the disbelievers on the believers' (Quran 4: 141). The notion of the principle of the rejection of domination is that God denies the domination of foreigners upon Muslims. On this base, the Muslim 'Umam' are required to work in order to preserve their independence and eventually to eliminate their dependence on various prospects of life.

In general, the principle of negation of domination consists of an affirmative and a repelling aspect: On the repelling front, the denial of domination of foreigners expresses the fate and the destiny of Muslims. On the positive note, it expresses the religious duty of the Islamic Ummah for the preservation of independence and the elimination of dependence in various horizons of life (Dehshiri 2001: VI/63).

According to the principle of the rejection of domination, the domination of foreign agents over the will of Muslim societies, in various contexts, 
should be blocked - in terms of political issues, disengagement, negligence towards oppression, confrontation with tyranny and colonialism, lack of authorization of foreign interference in the internal affairs of an Islamic country and the lack of permission for the infidelity of the unbelievers in making decisions. In terms of military, the lack of control over military capabilities and different military measures is emphasized. In terms of foreign relations, minimizing and ultimately getting rid of economic dependence and cultural influence are taken into consideration (Sajjadi 2004: 58).

In addition to the religious duty of the Islamic Ummah in maintaining independence, negating the domination of foreigners over Muslims, abolishing dependency and oppression to others, Muslims are also obliged to have a responsibility towards the non-Muslims in different forms. In this regard, Imam Ali states: "Be an enemy to oppression and of help to the oppressed" (Al-Sharif al-Razi 1991: letter 47). Similarly, the Prophet explicitly mentions that, "Anyone who hears a cry saying, 'O Muslim! (help!) but does not answer, is not a Muslim" (Al-Hur al-Amili 1988: XV/141).

Beyond the Islamic duty of protecting the oppressed Muslims, Imam Ali also had a strict mandate regarding the non-Muslims who were oppressed, as he said, "If a Muslim hears that in an Islamic land the ornaments of a Jewish lady have been taken by force and out of sadness of this catastrophe (the person) dies, there is no blame upon him" (Al-Sharif al-Razi 1991: The sermon of Jihad).

In line with the tasks outlined in the sacred laws of Islam, the foreign policy outlined after the victory of the Islamic Revolution of Iran was based on the same principle. In this regard, Imam Khomeini mentions: "We must work with the people of the world... and support those fighting injustice, the hungry and the poor, with all our being, and let this be understood as the principles of our foreign policy" (Imam Khomeini 1990: XX/140).

\subsection{Principle of Commitment and Observance of Treaties}

Fulfillment of covenants and oaths is considered one of the most significant commandments in Islam. The Quran emphasizes this principle in several verses. In some of the verses, reference is made to the observance of pledge and commitment, while in others the obligation to commit to a duty and its liability is mentioned. In a number of verses, the emphasis is laid upon respecting the covenant and fulfilling its commitment, whereas the failure to do so would inevitably lead to the violation of the treaty followed by undesired consequences. Some of the verses include: 
"O you who have faith! Keep your agreements..."

(Quran 5: 1).

"...So fulfill the treaty with them until [the end] of its term. Indeed, Allah loves the God-wary" (Quran 9: 4).

“...whoever fulfills his commitments and is wary of Allah - Allah indeed loves the God-wary" (Quran 3: 76).

“...[Believers are] those who keep their trusts and covenants"

(Quran 23: 8).

"... and fulfill your covenants; indeed, all covenants are accountable"

(Quran 17: 34).

In the practical lives of the infallible leaders, this principle can be seen in the general framework of their foreign policy as the head of Islamic states, even with non-Muslims. In this regard, the practical example of the Prophet can be used to emphasize his pioneering role in implementing the treaty of Hudaybiyyah, wherein $\mathrm{He}$, with utmost dislike, (still) in order to observe the rule of the treaty, was forced to return the newly converted Muslims of Mecca, who had made the journey to Medina after much torture and harassment.

Similarly, Imam Ali calls for the fulfillment of the covenants and agreements in political and military alliances. He considers them to be of utmost importance and condemns their violation. He says that if under the peace treaty you have accepted any obligations, respect those obligations scrupulously. It is a matter of trust and it must be faithfully upheld and whenever you have promised anything, keep the promise with all the strength that you command, for whatever differences of opinion might exist on other matters, there is nothing so noble as the fulfillment of a promise.

This is recognized even among non-Muslims, for they know the dire consequences which follow from the breaking of covenants. So, never make excuses when discharging your responsibilities and never break a promise or cheat your enemy. For a breach of promise is an act against God, and none except the provenly wicked act against God (Al-Sharif al-Razi 1991: letter 53).

The endeavor of the Infallibles to fulfill a commitment was such that during the battle of Siffin, when the battle was almost won by Imam Ali, a few members of his army forced him into arbitration and forced the Imam to accept the role of the 'hakmiyat', only to realize later that they had had been tricked into it and had committed a great mistake causing irreparable 
damages. With remorse and guilt, they came to the Imam and expressed their regret for the losses caused by the 'hakmiyat' treaty and called him to violate the treaty and go back to war with Mu'awiyah. The Imam replied, "Before the conclusion of the treaty, I anticipated all these harms and its negative consequences, and had warned you about them, but to no avail. Now that I have made a covenant, I will not violate it by any means. Woe to you, do you want me to turn my back on the declaration of my consent and my covenant?" (Al-Minqari 1991: 717)

Of the verses and narrations that have been mentioned, a few points are worth mentioning:

- The principle of observance of treaties is valid until the time of its expiration.

- It is prohibited to violate a covenant under satire excuses.

- Under no circumstances can a contract be violated, unless the other party violates it.

Using this moral principle of Islam, one can conclude that the most important factor in establishing friendly and peaceful relations between countries is by making use of such a treatise that is established by the free will and consent of different participating nations and countries. The conviction of governments towards each other would be in upholding their sides of commitments. This would serve as the most important asset for the international community. Building trust in it will make governments and nations stronger and more attached to each other, like the links of a chain.

\subsection{The Principle of Peaceful Coexistence}

Since the universal mission of Islam is to invite people towards the path of prosperity and perfection, it has always pursued a peaceful relationship in its foreign policies with different nations and societies. This principle is known as 'the principle of peaceful coexistence'.

The goal of peaceful coexistence in the abovementioned sense is to adhere to the principle of equality of sovereignty, respect for territorial integrity of countries, non-interference in the internal affairs of other countries, and the settlement of international issues through negotiation (Aqa Bakhshi 1987: 192).

In Islamic thought, peace and peaceful coexistence of human beings with different beliefs and thoughts is of significant value. The purpose of peace is not based on expediency, but rather peace itself is expedient because it is more consistent with human life. It is only in the state of peace that humans 
can excel and understand each other, reach an agreement, and finally, the unification of humanity towards the right path would be feasible.

In line with Islam's commitment to peaceful coexistence among humans, it should be noted that the term "peace" in its lexical form means co-existence, compromise and elimination of hatred among people. Similarly, the words "Salma" and "Salam", (root words for 'Islam') mean "peace" and "calmness" (Makarem Shirazi 1990: II/81).

In this context, the selection of 'Islam' as the name for the religion delivered by the Prophet Muhammad is in itself the best evidence to portray the importance of peace in the political system of Islam, and to recognize peace-making as a fundamental principle in the international relations of Islam. For example, in Surah Hujurat the following has been mentioned, "If two groups of the faithful fight one another, make peace between them. But if one party of them aggresses against the other, fight the one which aggresses until it returns to Allah's ordinance. Then, if it returns, make peace between them fairly, and do justice. Indeed, Allah loves the just" (Surah Hujarat, verse 9).

In narrations as well, an abundance of rewards has been mentioned for those striving to make peace, for example: "The reward of a person who creates peace among people is like the reward of a warrior who struggles in the way of God" (Makarem Shirazi 1995: X/371).

One of the main concerns in the field of international relations is the maintenance of peace and the prevention of war, and therefore Islam has focused heavily on it. Yet, despite the emphasis upon peace in the Quranic verses and the narrations, some Orientalists have claimed that Islam is the religion of war and sword, and that the ways of peace, negotiation and diplomacy are an alien phenomenon in Islam. In this context, Montesquieu writes: "The religion of Islam was imposed on people by the use of force and sword, because its basis was based on power and force..." (Montesquieu 1983: 670).

\subsubsection{The Cases for the Legitimacy of War}

In Islam, war is not a primary situation, but rather an exceptional one. It is only permissible if the peaceful means fail to provide a solution. In contrast to the norms of warfare, where the ultimate goal is sometimes a personal imposition of dominant nation, geographic expansion etc... Islam only permits a war in the following cases:

- To repel an enemy's invasion: "Fight in the way of Allah those who fight you, but do not transgress. Indeed, Allah does not like the transgressors" (Quran 2: 190). 
- Eliminating the oppression of the oppressed: “Those who are fought against are permitted [to fight] because they have been wronged, and Allah is indeed able to help them. Those who were expelled from their homes unjustly, only because they said, 'Allah is our Lord'. Had not Allah repulsed the people from one another, ruin would have befallen the monasteries, churches, synagogues and mosques in which Allah's name is mentioned greatly. Allah will surely help those who help Him. Indeed, Allah is all-strong, all-mighty" (Quran 22: 39-40). Similarly, in another verse it is mentioned, "Why should you not fight in the way of Allah and the abased men, women, and children who say, 'Our Lord, bring us out of this town whose people are wrongdoers, and appoint for us a guardian from you, and appoint for us a helper from you?" (Quran 4: 75)

- Fixing sedition: "Fight with them until there is no sedition and religion becomes exclusively for God, then if they relinquish, there shall be no reprisal except against the wrongdoers" (Quran 2: 193).

- Defending the land: “...why should we not fight in the way of Allah, when we have been expelled from our homes and [separated from] our children? So when fighting was prescribed for them, they turned back except a few of them and Allah knows best the wrongdoers" (Quran 2: 246).

- Violators of the treaty, conspirators and the initiators of war: "Will you not make war on people who broke their pledges and resolved to expel the Apostle, and opened [hostilities] against you initially?" (Quran 9: 13)

\subsubsection{Just War}

One of the distinctive features of Islam in comparison to other religions is that Islam, even in cases of war, ordains a just war. It allows killing enemies strictly on the battlefields alone and forbids the killing of those who did not participate in it or weren't capable of doing so. These groups include children, women, the elderly, delegates, monks, priests, workers, innocent people, and farmers (Abu 'Id 2012: 201-210).

In addition, Islam has also forbidden cowardly assaults, use of unconventional weapons and attacks on holy places (Islam and Humanitarian International Law 2013: 238-239).

It is worth mentioning that in Islam the prisoners of war ought to be treated respectably and the Muslims are ordered to act with beneficence 'ihsan' towards them. In addition, religious leaders have acted in such an 
exemplary manner that it is very hard for the common mind to comprehend in the contemporary world. Among these orders are: being good towards the prisoners of war, providing them with water and food, providing shelter and clothing, giving them jobs, providing treatment for the wounded, preventing captive killings etc... (Azimi Shooshtari 2007: 171-172).

One of the things that is less evident in the human rights conventions and protocols is the way and manner of killing an enemy during wars. In some cases, the victorious groups allow themselves to hurt the enemy in any way possible. However, Islam has codified laws in this field so as to prevent the merciless killings of human beings by instructing Muslims to observe the principles of humanity, even in killing the enemy in a war. The code forbids mutilation, choking, burning, and strangulation (Islam and Humanitarian International Law 2013: 248-249).

\section{Conclusion}

Given the intrinsic orientation of humankind towards society, humans in their mutual life form communities at different levels, such as families, tribes, ethnic groups, nations, and the world. The primary goal in such formations is self-interest. However, in order to avoid conflicts and their harmful consequences while simultaneously securing their own interest, humans are in need of certain criteria to adhere to.

International relations are one of the most important levels of human interaction. It would be immune to vulnerability as long as it is based on rational and reasonable criteria. Among the various principles in regulating international relations, the role of ethics (observance or non-observance of ethical rules) in international relations is one of the central issues. There are three basic perspectives on it. The first group does not pay attention to ethical values and merely seeks to explain the visible elements, various circumstances and the relationship between them. The second group, despite accepting ethical values in the behavior of actors in international relations, fails to judge whether the values or ethics are correct or incorrect. Meanwhile, the third group gives values and ethics a central role in international relations and values morality in the international arena. It addresses the international relations as they ought to be.

The religion of Islam, which belongs to the third group, deals with the do's and don'ts of international relations and provides an ethical approach to describing and prescribing the international relations as they should be. It proposes a system of ideas or a set of related and consistent logical propositions that consider not only the interests of Islamic nations and governments, but also of others. The system provides a framework for a just and fair 
international arrangement in which humans (in both personal and collective terms) reach perfection and prosperity. It seeks the interests of humanity, as a whole, throughout the world. The desired goal of Islam as a worldwide religion is to seek to design and establish a global moral community beyond the national governments in order to realize the human and moral values in the framework of a political community in a transnational justice-based system. In such a moral-political community, Islam strives to provide security and prosperity to all humankind. In this regard, God and justice are considered pivotal in the foundation of international Islamic relations.

Due to the fact that Islam is a universal religion and is not bounded to a particular language, culture, belief or race, the subject of its messages and commandments in pursuing ethical principles in the international arena is global and comprehensive. The main principles prescribed by Islam in the international arena are:

- Alliance of societies based on pure, inherent human nature;

- The principle of equality of nations on the basis of human dignity, negation of ethnicity and racism;

- The principle of non-violent intervention to promote belief (freedom of opinion);

- The principle of the rejection of domination;

- The principle of protecting the oppressed from the oppressor;

- Principle of observance and Commitment to treatise with Enemies;

- The principle of peaceful coexistence (the emphasis on peace, the legitimacy of war in cases such as: repulsion of the enemy's aggression, defending the oppressed from the oppression, resolving treachery, defending the land, confronting the violators of a treaty, conspirators and the initiators of war);

- Emphasize just war (forbidding the killing of non-combatants, waging a cowardly invasion, the use of unconventional weapons, prohibition of attacks on holy places, and engagement with prisoners of war...).

Received: November $14^{\text {th }}, 2018$.

Accepted: December 25 ${ }^{\text {th }}, 2018$.

\section{References}

Holy Quran.

Abu 'Id, Khalil Arif (2012), International Relations and Islamic Jurisprudence, translated by Seyyed Adnan Mohaqiq, Tehran, Imam Sadiq University. 
Alavi, Seyyed Mahmoud (2007), The Legal Principles of International Relations, Tehran, Amir Kabir Publications.

Al-Hur al-Amili, Muhammad ibn al-Hasan (1988), Wasail al-Shia, Beirut, Dar Al-Ihya al-Turath al-Arabi.

Al-Minqari, Nasr ibn Muzahim (1991), Peykar Siffin, translated by Praviz Atabaki, Tehran, Shirkat ilmi wa farhangi.

Al-Sharif al-Razi, Abul-Hasan Muhammad (1991), Nahj al-Balaghah, Tehran, Publication and teaching of the Islamic Revolution.

Aqa Bakhshi, Ali (1987), Political Science Culture, Tehran, Behrang Publishing.

Azimi Shooshtari, Abbas-Ali (2007), Islamic International Law, Tehran, Dadgostar publication.

Dehghani Firoozabadi, Seyyed Jalal (2009), Ethics and theorizing in international relations, Tehran, Mehr News Agency.

Dehshiri, Muhammad Reza (2001), "Principles and Principles of Islamic Diplomacy", in: The Collection of Imam Khomeini Congress and Ideas of the Islamic State, Tehran, Institute for the Setting up and Publication of Imam Khomeini’s Works.

Montesquieu, Charles-Louis de Secondat (1983), The Spirit of the Laws, translated by A. Mohtadi, Tehran, Amir Kabir.

Duverger, Maurice (1979), The Study of Politics, translated by A. Ghazi, Tehran, Javidan Publishing.

Hamidullah, Muhammed (2001), International Islamic Movement, translated by Seyyed Mostafa Mohaghegh Damad, Tehran, Islamic Science Publishing Center.

Imam Khomeini, Sayyid Ruhollah (1990), Sahifeh Noor (Imam Khomeinis Guidance Collection), Tehran, Islamic Cultural Organization of the Islamic Revolution.

Islam and Humanitarian International Law (2013), Tehran, Mizan publication.

Javadi Amoli, Abdullah (2009), International Relations in Islam, Qom, Isra Publication.

Kiani, Nima (2009), Political Ethics, Tehran, Office of Social Planning and Cultural Studies, Department of Culture and Social Affairs, Ministry of Science.

Makarem Shirazi, Naser (1990), Tafsir Nemooneh, Tehran, Dar al-Kutub al-islamiyah.

Makarem Shirazi, Naser (1995), Message of Quran, Qom, Imam Ali ibn Abi Talib seminary.

Sajjadi, Abdul-Qayyum (2004), Diplomacy and Islamic Political Behavior, Qom, Bustan publication.

Tabataba'i, Muhammad Husain (1994), Al-Mizan, Qom, Jame’eye Mudarresin.

Zakerian, Mehdi (2011), Ethics and International Relations, Tehran, Imam Sadiq University. 